\title{
Deleterious ABRAXAS1 Gene Mutation
}

National Cancer Institute

\section{Source}

National Cancer Institute. Deleterious ABRAXAS1 Gene Mutation. NCI Thesaurus. Code C156013.

A change in the nucleotide sequence of the ABRAXAS1 gene that is associated with increased risk of disease. 